\title{
Binding of receptor for advanced glycation end products (RAGE) ligands is not sufficient to induce inflammatory signals: lack of activity of endotoxin-free albumin-derived advanced glycation end products
}

\author{
J. V. Valencia ${ }^{1,2}$ - M. Mone ${ }^{1}$ C. Koehne ${ }^{1}$ J. Rediske ${ }^{1}$ T. E. Hughes ${ }^{1,2}$ \\ ${ }^{1}$ Novartis Institutes for BioMedical Research, Cambridge, Massachusetts, USA \\ 2 Department of Molecular Genetics, Microbiology and Immunology, University of Medicine and Dentistry of New Jersey, \\ Piscataway, USA
}

\begin{abstract}
Aims/hypothesis. Activation of the receptor for advanced glycation end products (RAGE) reportedly triggers cellular responses implicated in the pathogenesis of diabetes, such as increasing vascular cell adhesion molecule-1 (VCAM-1) expression on vascular endothelial cells and inducing TNF- $\alpha$ secretion by mononuclear cells. The objective of this study was to evaluate whether RAGE binding affinity of AGEBSAs and cellular activation correlate.

Methods. To produce AGEs with varying glycation, bovine albumin AGEs were prepared with $500 \mathrm{mmol} / \mathrm{l}$ of glucose, fructose or ribose at times of incubation from 1 to 12 weeks. In addition, AGE-BSA was generated using either glyoxylic acid or glycolaldehyde. Cellular binding of the AGE-BSAs and the effect on endothelial cell VCAM-1 expression were studied in RAGE-expressing human microvascular endothelial cell line- 4 cells. Induction of TNF- $\alpha$ secretion was assessed using RAGE-expressing human peripheral blood mononuclear cells (PBMCs).
\end{abstract}

Results. Cellular binding of the different AGE preparations correlated well with RAGE affinity. Interestingly, we found that the AGE preparations, which were essentially endotoxin free $(\leq 0.2 \mathrm{ng} / \mathrm{mg}$ protein), were incapable of inducing VCAM- 1 or TNF- $\alpha$ secretion regardless of RAGE binding affinity, AGE concentration or incubation time. In contrast, the reported RAGE ligand S100b was confirmed to induce VCAM-1 expression on endothelial cells and TNF- $\alpha$ secretion by PBMCs after $24 \mathrm{~h}$ of treatment.

Conclusions/interpretation. The results of this study suggest that AGE modification and high RAGE binding affinity are not sufficient to generate pro-inflammatory signalling molecules. Thus, RAGE binding affinity of AGE-BSAs does not seem to correlate with cellular activation. Our findings using AGEs with strong RAGE-binding properties indicate that AGEs may not uniformly play a role in cellular activation.

Keywords AGE - Glycation · Inflammation · Maillard reaction $\cdot \mathrm{RAGE} \cdot$ Serum albumin
Received: 2 July 2003 / Accepted: 22 January 2004 Published online: 1 May 2004

(C) Springer-Verlag 2004

\section{T. E. Hughes (}

Department of Molecular Genetics,

Microbiology and Immunology,

University of Medicine and Dentistry of New Jersey,

675 Hoes Lane, Piscataway, New Jersey 08854, USA

E-mail: thomase.hughes@ pharma.novartis.com

Tel.: +1-617-8717300, Fax: +1-617-8717050
Abbreviations: Ctrl-BSA, BSA incubated in the absence of modifying agent . FruBSA, BSA incubated with fructose . G50 BSA, BSA incubated with $50 \mathrm{mmol} / 1$ glycolaldehyde . G70 BSA, BSA incubated with $70 \mathrm{mmol} / \mathrm{l}$ glycolaldehyde · GA BSA, BSA incubated with glyoxylic acid · GluBSA, BSA incubated with glucose - HMEC-4, human microvascular endothelial cell line-4 $\cdot$ HRP, horseradish peroxidase . hsRAGE, human-soluble RAGE $\cdot$ I $\mathrm{RB}-\alpha$, inhibitor of nuclear factor- $\kappa \mathrm{B} \cdot \mathrm{LPS}$, lipopolysaccharide/endotoxin · $\mathrm{NF}-\kappa \mathrm{B}$, nuclear factor- $\kappa \mathrm{B} \cdot \mathrm{PBMCs}$, peripheral blood mononuclear cells · RAGE, receptor for AGE - RibBSA, BSA incubated with ribose $\cdot \mathrm{RT}$, room temperature . SRB, sulphorhodamine B - TBS-casein, Tris-buffered saline plus casein - VCAM-1, vascular cell adhesion molecule-1 


\section{Introduction}

Type 2 diabetes is a common chronic disease with a high risk of macrovascular and microvascular complications that lead to disability and premature death. Hyperglycaemia has been shown to be responsible for the functional and morphological changes associated with these diabetic complications [1,2]. Other underlying factors could contribute to these vascular complications, including hypertension, dislipidaemia, inflammation and genetics $[3,4,5]$. A common pathway believed to lead to vascular dysfunction and atherogenesis is chronic activation of the endothelium, which promotes a procoagulant and a proinflammatory state $[6,7]$. Although the mechanisms underlying the vascular dysfunction seen in diabetes are not fully understood, several hypotheses have been proposed, including activation of the endothelium by AGEs [8].

AGEs, a heterogeneous group of complex structures that form non-enzymatically when reducing sugars, react with free amino groups on proteins, lipids or nucleic acids. The formation of AGEs has been found to occur in ageing, and at an accelerated rate in diabetic patients [9]. For example, pentosidine and $N^{\varepsilon}$-(carboxymethyl) lysine, known end products of these reactions, have been identified in the vasculature and tissues of patients with diabetes, and accumulate with age in all animal species tested $[10,11,12$, 13, 14]. The deposition of these covalent adducts on various proteins has been reported to contribute to the development of the complications of ageing and diabetes through direct chemical- (covalent crosslink formation) and cell surface receptor-mediated pathways [15].

The most characterised AGE-binding protein is the receptor for AGE (RAGE). RAGE, a 45-M protein belonging to the immunoglobulin superfamily, is present on the cell surface of a variety of cells including endothelial cells, mononuclear phagocytes, hepatocytes, smooth muscle cells, certain neurons and mesangial cells $[16,17]$. RAGE is a multiligand receptor, and has also been shown to bind to several proteins in the S100 family including S100A12 (extracellular newly identified RAGE-binding protein) and S100b $[18,19]$. Activation of RAGE by its various ligands reportedly induces a variety of proinflammatory and procoagulant cellular responses, resulting from the activation of nuclear factor- $\kappa \mathrm{B}(\mathrm{NF}-\kappa \mathrm{B})$ [20]. For example, increased expression of vascular cell adhesion molecule-1 (VCAM-1) has been shown to be increased after exposure of cultured endothelial cells to AGEs or to certain S100 proteins via RAGE activation $[18,21]$. Both AGEs and S100A12 have also been reported to induce TNF- $\alpha$ secretion by mononuclear cells $[18,22]$ through RAGE activation. In addition, the "Two-hit model" proposed by Stern and Schmidt [23] suggests that cells chronically exposed to AGEs (first hit) results in a low level of cellular activation, so that if a second aggravation occurs, for example a bacterial infection, those primed cells will have a more exacerbated response compared to cells that were not chronically exposed to AGEs. Thus, engagement of RAGE potentially plays a role in the pathogenesis of the chronic, low-grade inflammatory state associated with diabetes. Although the precise chemical nature of structures capable of RAGE binding remains to be established, some evidence supports a role of $N^{\varepsilon}$-(carboxymethyl) lysine as a main AGE-RAGE ligand [24].

Previously, we have found that RAGE-binding AGEs can be created reproducibly using the reducing sugars, glucose, fructose and ribose, and two highly reactive carbonyls, glyoxylic acid and glycolaldehyde [25]. These AGEs were generated in a manner that does not lead to significant endotoxin contamination, a major potential driver of inflammatory cellular responses. The objective of this study was to evaluate the biological activity of those previously characterised AGE preparations to determine whether RAGE binding affinity correlates with cellular activation. To this end, two biological assays were employed, one that measured VCAM-1 induction on the surface of an endothelial cell line (HMEC-4), and another that measured TNF- $\alpha$ secretion by primary human peripheral blood mononuclear cells (PBMCs).

Interestingly, we found that the AGE preparations, which were essentially endotoxin-free $(\leq 0.2 \mathrm{ng} / \mathrm{mg}$ protein; $\leq 2$ endotoxin units/mg protein), were incapable of inducing VCAM-1 or TNF- $\alpha$ secretion regardless of RAGE binding affinity. In addition, the "Two-hit model" [23] was tested, and we found that cells preincubated with AGEs did not have an exacerbated response to low levels of endotoxin. Despite previous reports, we have found that AGEs generated by diverse protocols were not capable of inducing inflammatory cellular responses in vitro. The results of this study suggest that AGE modification alone is not sufficient to generate proinflammatory signalling molecules. Potential explanations for the discrepancies between the various AGE biological signalling studies in the literature will be discussed.

\section{Materials and methods}

Materials. Chemicals were obtained from Sigma (St. Louis, Mo., USA) unless noted below. Heparin was purchased from Elkins-Sinn (Cherry Hill, N.J., USA). Glacial acetic acid was obtained from Aldrich Chemical Company (Milwaukee, Wis., USA). PBS (10×) and Complete Mini protease inhibitor cocktail tablets were purchased from Roche Diagnostics (Mannheim, Germany). Endotoxin-free distilled $\mathrm{H}_{2} \mathrm{O}$, sterile PBS without calcium and magnesium, MCDB 131 endothelial cell media, RPMI 1640 with L-glutamine, heat-inactivated fetal bovine serum, L-glutamine, antibiotic/antimycotic, $0.05 \%$ trypsin/0.53 mmol/l EDTA, penicillin and streptomycin, and BCIP/NBT western developing substrate were purchased from Gibco BRL/Life Technologies (Gaithersburg, Md., USA). 
Sterilisation filters (Express filter; $0.22 \mu \mathrm{m} ; 250 \mathrm{ml}$ capacity) were obtained from Millipore (Bedford, Mass., USA). Bicinchoninic acid protein assay kit, casein blocking buffer, Imject Maleimide keyhole limpet haemocyanin and ovalbumin conjugation kits, gentle binding buffer and gentle elution buffer were purchased from Pierce (Rockford, Ill., USA). Tissue culture plates and plates treated with Optilux Plus scintillation tissue culture were purchased from Fisher Scientific (Pittsburg, Pa., USA). SDS-PAGE and western blot supplies were purchased from Invitrogen (Carlsbad, Calif., USA). Hespan was purchased from Braun (Irving, Calif., USA). Antibodies were obtained as follows: mouse monoclonal anti-human VCAM-1 antibody (clone: BBIG-V1) from R\&D Systems (Minneapolis, Minn., USA), rabbit polyclonal anti-I $\mathrm{B} \alpha$ from Santa Cruz Biotechnology (Santa Cruz, Calif., USA), goat anti-rabbit conjugated to alkaline phosphatase from BioRad (Hercules, Calif., USA). Human TNF- $\alpha$ ELISA plates were obtained from Pierce-Endogen (Rockford, Ill., USA). Sephacryl S-100 resin, SP-Sepharose fast-flow resin, and protein-G Sepharose (Gamma bind plus) were purchased from Amersham-Pharmacia Biotech (Piscataway, N.J., USA). Optiphase super mix scintillation fluid was obtained from Wallac (Turku, Finland). Picrogreen double-stranded DNA quantification kit was purchased from Molecular Probes (Eugene, Ore., USA).

Preparation of modified BSA preparations. At a concentration of $500 \mathrm{mmol} / \mathrm{l}$, glucose BSA (Glu500 BSA), fructose BSA (Fru500BSA), ribose BSA (Rib500BSA) and control BSA (Ctrl-BSA) were prepared and characterised as previously described [25]. Endotoxin levels were measured by Associates of Cape Cod (Falmouth, Mass., USA) using the gel clot method, and were found to be less than $0.2 \mathrm{ng} / \mathrm{mg}$ ( 2 endotoxin units/mg protein) AGE-BSA. Glyoxylic-acid-derived AGEs (GA BSA) or glycolaldehyde-derived AGEs (G BSA) were also generated as previously described $[11,25]$. The measurement of human-soluble RAGE (hsRAGE) binding to modified BSAs was carried out as described previously [25].

Cell culture. Human microvascular endothelial cells (HMEC-4) were obtained from Dr Edwin Ades (Center for Disease Control, Atlanta, Ga., USA). HMEC-4 cells were derived from human foreskin and immortalised by constitutive expression of the T-antigen of the SV40 virus [26]. Monolayers were propagated from passages 20-26 in growth medium (MCDB131, supplemented with $10 \%$ heat-inactivated FBS, 2 mmol/l L-glutamine, $10 \mathrm{ng} / \mathrm{ml} \mathrm{EGF,} 1 \mu \mathrm{g} / \mathrm{ml}$ hydrocortisone and $1 \%$ antibiotic-antimycotic) in $5 \% \mathrm{CO}_{2}$ at $37^{\circ} \mathrm{C}$. For AGE-binding experiments and the VCAM-1 assay, confluent monolayers were obtained by seeding on $0.2 \%$ gelatin-coated 96 -well plates at a density of 50000 cells per well and then culturing for 4 days. Various test solutions were diluted in treatment media (same media described above except the FBS was reduced to 5\%).

Generation of anti-BSA antibody. Rabbit IgG from GA-BSAimmunised animals were isolated from serum by protein G-sepharose chromatography. Total IgG was further purified using a column of BSA immobilised on cross-linked, beaded agarose. Final concentration of IgG was $1.7 \mathrm{mg} / \mathrm{ml}$. Via ELISA testing, the anti-BSA antibody was found to recognise both native BSA and the sugar-derived AGE-BSAs.

Cell-based BSA-binding ELISA. The cells were directly treated with Ctrl- or AGE-BSAs or, for the competition experiments, were preincubated ( 3 or $18 \mathrm{~h}$ ) with the potential blocker, polyanionic molecules or hsRAGE respectively. Then the Ctrl- or AGE-BSAs were added to the cells at $37{ }^{\circ} \mathrm{C}$ for various time periods. All HMEC-4 treatments were diluted in treatment media
(125 $\mu \mathrm{l} /$ well). Following incubation of cells with various treatments, plates were washed with PBS and fixed with $2 \%$ paraformaldehyde. After washing with PBS, total cell protein per well was determined using the sulphonated dye, sulphorhodamine B (SRB) [27]. Cellular association of Ctrl-BSA or AGE-BSA was assessed by ELISA. Following the SRB evaluation, plates were washed with PBS and blocked with Tris-buffered saline plus casein (TBS-casein; $150 \mu \mathrm{l} /$ well) at room temperature (RT) for at least $1 \mathrm{~h}$. The fixed and blocked cells were incubated overnight at $4{ }^{\circ} \mathrm{C}$ with $70 \mu \mathrm{l} /$ well of the rabbit polyclonal anti-BSA antibody diluted 1:2000 in TBS-casein blocking solution. The cells were washed with PBS, followed by incubation with $70 \mu \mathrm{l} /$ well of goat anti-rabbit horseradish peroxidase (HRP) antibody diluted 1:3000 in TBS-casein-blocking solution at RT for $3 \mathrm{~h}$. After washing with PBS, plates were developed at RT for $10 \mathrm{~min}$ with $125 \mu \mathrm{l} /$ well of the HRP substrate solution $\left(25 \mu \mathrm{l}\right.$ of $31.3 \% \mathrm{H}_{2} \mathrm{O}_{2}$ and $10 \mathrm{mg}$ of $o$-phenylenediamine dissolved in $25 \mathrm{ml}$ of developing buffer [34.7 mmol/1 sodium citrate and $66.7 \mathrm{mmol} / \mathrm{l}$ sodium monophosphate, $\mathrm{pH} 5.0]$ ). The reaction was stopped with $25 \mu \mathrm{l} /$ well of $4 \mathrm{~N}$ sulphuric acid and the absorbance was measured at $450 \mathrm{~nm}$. Values are expressed as cell-associated BSA, which corresponds to the following: [(Sample BSA ELISA value)/(Sample SRB)]-[(HRP blank BSA ELISA value)/(HRP blank SRB)].

Production and purification of polyclonal anti-RAGE antibody. A 14-amino-acid stretch (KGAPKKPPQRLEWK) found in the V-domain of RAGE was synthesised and HPLC purified by ResGen (Invitrogen) with a cysteine added to the N-terminus of the peptide for conjugation. The peptide was covalently conjugated to the haptens, keyhole limpet haemocyanin and ovalbumin, using Imject Maleimide kits (Pierce) according to the manufacturer's instructions. The RAGE peptide keyhole limpet haemocyanin conjugate was sent to Covance (Denver, Pa., USA) for immunisation of rabbits using their accelerated protocol. Total $\mathrm{IgG}$ from the rabbit serum was purified using a protein-G sepharose column. For affinity purification, total IgG was loaded onto a column of the RAGE peptide ovalbumin conjugate covalently cross-linked to cyanogen-bromideactivated sepharose 4B. The anti-RAGE IgG was filter-sterilised using a $0.2 \mu \mathrm{m}$ syringe filter $([\operatorname{IgG}] \geq 1 \mathrm{mg} / \mathrm{ml})$.

Radioligand-based binding assay. Rib500 BSA wk6 was 125Iradiolabelled by ICN Biomedicals (Irvine, Calif., USA) using the lactoperoxidase method. Radioligand binding assays were performed in 96-well white plates treated with Optilux Plus scintillation tissue culture, to which HMEC-4 cells were plated. Cells were either directly treated with ${ }^{125}$ I-Rib500 BSA wk6 or, for the competition experiments, were preincubated (for $18 \mathrm{~h}$ at $37^{\circ} \mathrm{C}$ ) with the potential blocker (unlabelled AGEBSAs, S100b, polyanionic molecules) and then the ${ }^{125}$ I-Rib500 BSA wk6 was added to the cells at $37{ }^{\circ} \mathrm{C}$ for $1 \mathrm{~h}$. For hsRAGE treatments, ${ }^{125}$ I-Rib500 BSA wk6 was incubated with hsRAGE for $18 \mathrm{~h}$ at RT, and then the mixture was incubated with the cells for $1 \mathrm{~h}$ at $37{ }^{\circ} \mathrm{C}$. Following cellular treatments, plates were washed with PBS and cells were lysed using $100 \mu \mathrm{l} /$ well solubilisation buffer $(20 \mathrm{mmol} / \mathrm{l}$ Tris- $\mathrm{HCl}, 0.14 \mathrm{~mol} / \mathrm{l} \mathrm{NaCl}$, $5 \mathrm{mmol} / \mathrm{l}$ EDTA and $1 \%$ Triton X100, pH 7.5). After shaking plates for $1 \mathrm{~h}$ at RT, $150 \mu \mathrm{l} /$ well of Optiphase super mix scintillation fluid was added, and the plates were incubated overnight before reading. Non-specific binding of 125 I-Rib500 BSA wk6 was determined by adding 100-fold molar excess of unlabelled Rib500 BSA wk6, and was found to be $10 \%$ or less of total binding. For each treatment, the background levels (media control) were subtracted. Total cell number per well was estimated on duplicate plates using Picogreen Reagent to estimate double-stranded DNA content. 
Assay for cell surface VCAM-1. The HMEC-4 cells do not express VCAM-1 constitutively, but it can be induced by various stimuli. The cells were treated with $125 \mu \mathrm{l} /$ well of Ctrl-BSA, AGE-BSA or S100b diluted in MCDB131 treatment medium at $37{ }^{\circ} \mathrm{C}$ for $18 \mathrm{~h}$. On each plate, medium alone was included as a negative control, and $20 \mathrm{ng} / \mathrm{ml}$ human TNF- $\alpha$ and $100 \mathrm{ng} / \mathrm{ml}$ lipopolysaccharide/endotoxin (LPS) were included as positive controls for VCAM-1 induction. Following $18 \mathrm{~h}$ of incubation, the cells were treated identically to the BSA ELISA, except the BSA antibody was replaced with $70 \mu \mathrm{l} /$ well of mouse monoclonal anti-VCAM-1 antibody diluted 1:200 in TBS-casein blocking solution. The secondary antibody used for the VCAM-1 assay was a goat anti-mouse HRP antibody diluted 1:3000 in TBS-casein blocking solution. Fold VCAM-1 induction was calculated using the following formula: normalised value $=[($ Sample VCAM-1) $/($ Sample SRB $)]-[($ HRP blank VCAM-1)/(HRP blank SRB)].

PBMC isolation and TNF- $\alpha$ production assay. We obtained 1 unit of citrated whole blood from healthy volunteers, which was then mixed with Hespan $(6 \%$ hetastarch in $0.9 \% \mathrm{NaCl})$ at a blood:hespan ratio of 2.3:1. After the red blood cells sedimented, PBMCs were isolated using Histopaque centrifugation according to the manufacturer's instructions. Isolated PBMCs were suspended in RPMI 1640 with 2 mmol/1 L-glutamine, 100 units $/ \mathrm{ml}$ penicillin and streptomycin and $10 \%$ heat-inactivated FBS at $5 \times 10^{6} / \mathrm{ml}$ and distributed into 96-well culture plates (100 $\mu \mathrm{l}$ cell suspension/well). After overnight incubation at $37{ }^{\circ} \mathrm{C}$, the cells were stimulated with AGE-BSAs $(200 \mu \mathrm{g} / \mathrm{ml})$ or the positive control stimuli $100 \mathrm{ng} / \mathrm{ml}$ LPS for $18 \mathrm{~h}$. The amount of TNF- $\alpha$ in the conditioned medium in triplicate conditions was determined by ELISA according to the vendor protocol. Unless noted, the data are expressed as mean $\mathrm{pg} / \mathrm{ml} \mathrm{TNF}$ \pm SEM for multiple experiments.

Western blot analysis. Cells were grown to confluence in 6-well plates. For $\mathrm{I} \kappa \mathrm{B} \alpha$ westerns, cells were treated with $20 \mathrm{ng} / \mathrm{ml} \mathrm{TNF-} \alpha, 300 \mu \mathrm{g} / \mathrm{ml} \mathrm{S100b}$ or Rib500 BSA wk6 or $300 \mathrm{ng} / \mathrm{ml}$ Rib500 BSA wk6 for the indicated time periods. For RAGE western, cells were exposed to media only. The cells in each well were washed with ice-cold PBS and scraped into $0.4 \mathrm{ml}$ of ice-cold extraction buffer (20 mmol/l HEPES, $\mathrm{pH} 7.2,100 \mathrm{mmol} / \mathrm{l} \mathrm{NaCl}, 1 \%$ Triton X-100 and $10 \%$ glycerol) supplemented with protease inhibitors. The lysates were subjected to western blot analysis using standard techniques, and blots were incubated for $4 \mathrm{~h}$ at RT with the primary antibody

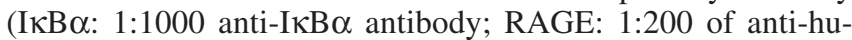
man RAGE antibody). The AP system was used for detection.

Data analysis. Triplicate experiments were analysed unless otherwise noted. Statistical comparisons among groups were determined using one-way ANOVA. Where indicated, individual comparisons were performed using the Student's $t$ test. A $p$ value of less than 0.05 was considered statistically significant.

\section{Results}

RAGE binding affinity of the AGE-BSAs and cellular association. Using a cell-free assay, the RAGE binding affinity for the various AGE-BSAs was determined based on their ability to compete with G50 BSA for binding to hsRAGE. Figure 1a shows the percentage of hsRAGE binding displaced in this assay by $100 \mu \mathrm{g} / \mathrm{ml}$ of each test AGE-BSA. Three weeks of a

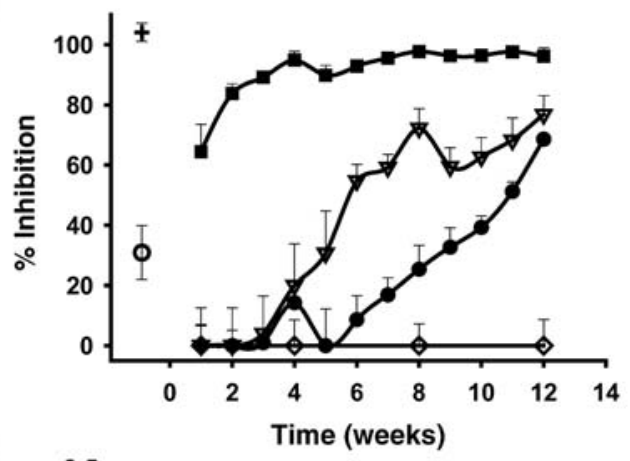

b

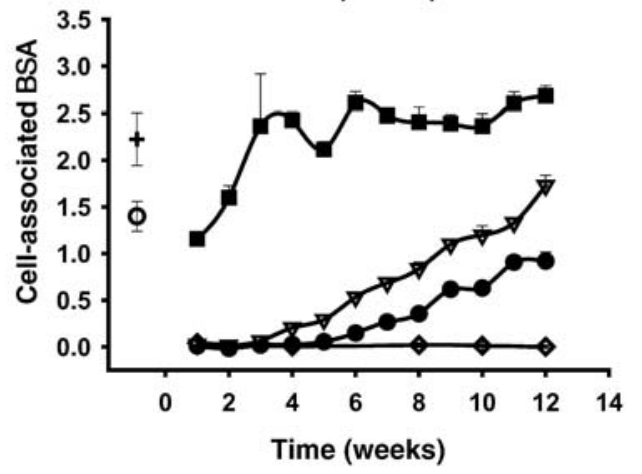

c

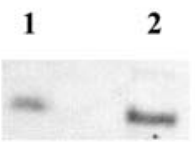

Fig. 1. AGE binding to hsRAGE and HMEC-4 cells. a. Inhibition of hsRAGE binding in a cell-free assay observed using $100 \mu \mathrm{g} / \mathrm{ml}$ AGE- or Ctrl-BSAs prepared by incubation with and without modifying sugar for $0-12$ weeks. b. HMEC-4 cell association of BSA following incubation with $100 \mu \mathrm{g} / \mathrm{ml}$ of AGE-BSA or Ctrl-BSA for $18 \mathrm{~h}$ at $37{ }^{\circ} \mathrm{C}$ with $100 \mu \mathrm{g} / \mathrm{ml}$ of AGE-BSA or Ctrl-BSA. Cells were incubated and washed, and BSA ELISA binding assay was performed as described in Materials and methods. Ctrl-BSA $(\diamond)$, Glu500 BSA (๑), Fru500 BSA ( $\nabla)$, Rib500 BSA (ם), G70 BSA (+) and GA BSA $(\bigcirc)$. Values are means \pm SEM for at least three independent experiments. c. Western blot analysis showing the presence of RAGE protein in HMEC-4 cell extract (lane 1) and human PBMC cell extract (lane 2)

incubation with ribose generated AGE-BSAs with maximal displacement of hsRAGE. In contrast, Glu500- and Fru500-BSAs were incapable of displacing hsRAGE at the 3-week time point. After 12 weeks of incubation with glucose or fructose, the resulting AGE-BSAs displaced about $70 \%$ of hsRAGE.

As shown in Figure 1c, the presence of RAGE on HMEC-4 cells was demonstrated by western blot. After incubating the endothelial cell line HMEC-4 with $100 \mu \mathrm{g} / \mathrm{ml}$ of each test AGE-BSA, a similar pattern to the cell-free hsRAGE binding assay was observed (Fig. 1b). AGEs that showed a high hsRAGE binding affinity in the cell-free assay also showed a high level of cellular association.

To further understand the selectivity of the AGEBSA cellular interaction, we utilised a radioligand assay based on previously established methods [16, 28]. 


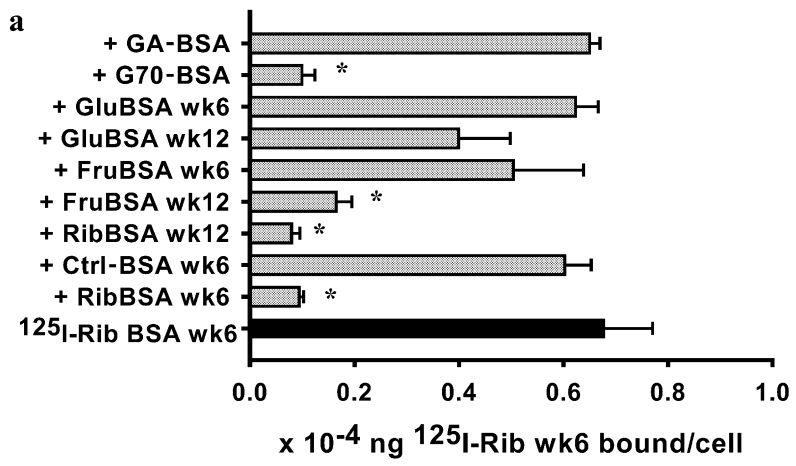

b

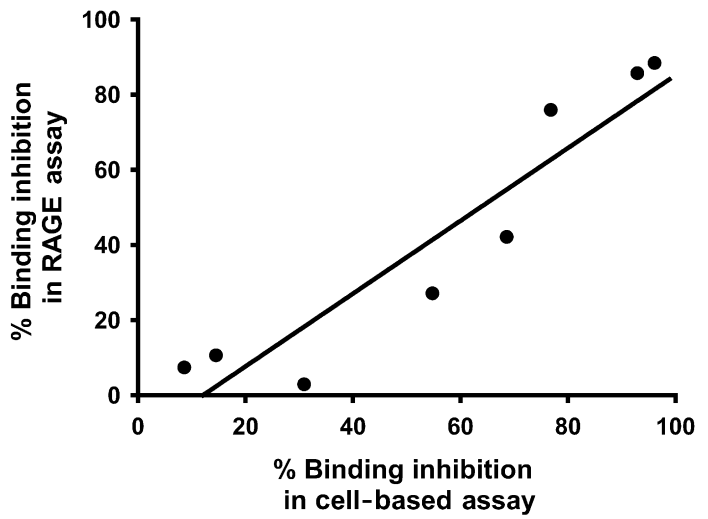

Fig. 2. Competitive inhibition of 125I-Rib500 BSA wk6 binding to HMEC-4 cells. Using ${ }^{125}$ I-Rib500 BSA wk6, the relative cellular association of various unlabelled AGE-BSAs was evaluated. a. Following an overnight preincubation $\left(37{ }^{\circ} \mathrm{C}\right)$ of HMEC-4 cells with 100-fold excess of unlabelled AGE-BSA $(80 \mu \mathrm{g} /$ well $),{ }^{125} \mathrm{I}-\mathrm{Rib} 500 \mathrm{BSA}$ wk6 $(0.65 \mu \mathrm{g} /$ well $)$ was added and allowed to bind for $1 \mathrm{~h}$ at $37^{\circ} \mathrm{C}$. b. Correlation of binding inhibition by AGE-BSAs in cell-free hsRAGE binding assay with binding inhibition of 125I-Rib500 BSA wk6 to HMEC-4 cells; $r=0.95$. Values are means \pm range for two independent experiments. * indicates that values are significantly different compared with ${ }^{125}$ I-Rib500 BSA wk6 alone, $p<0.005$

This radioligand-based assay provided a method to compare the cellular association of various AGEBSAs relative to the binding of ${ }^{125}$ I-Rib500 BSA wk6. 125I-AGE-BSA:endothelial cell binding was inhibited by excess unlabelled Rib500 BSA wk6 and other AGE-BSAs, but not by native BSA (Fig. 2a). AGEBSA binding assessed in this manner correlated with AGE-BSA inhibition of hsRAGE binding in the cellfree binding assay (Fig. 2b).

We also tested the ability of the polyanionic AGEbinding inhibitors heparin, fucoidan and dextran sulphate to inhibit AGE-BSA cellular association [29, 30]. All three polyanionic molecules inhibited binding of AGE-BSAs to HMEC-4 cells (Fig. 3a, b). In addition, AGE binding was partially blocked by pretreating the cells with S100b, another reported RAGE ligand (Fig. 3a, b). Preincubation of AGE-BSA with hsRAGE also inhibited cellular binding (Fig. 3a, b). It is worth noting that the results obtained in the BSA ELISA were the same in the radioligand-based binding assay.

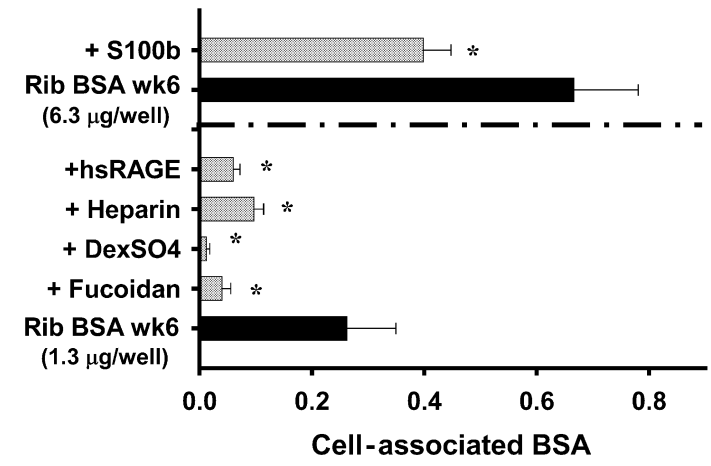

b

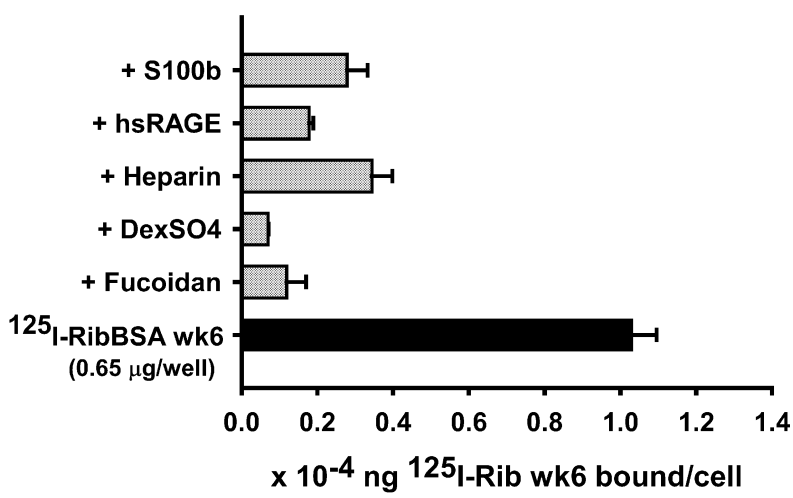

Fig. 3. Effect of polyanionic molecules, S100b and hsRAGE, on cellular association of AGEs. a. Cell surface BSA ELISA with HMEC-4 cells. b. Binding of 125 I-Rib500 BSA wk6 to HMEC-4 cells. For BSA-based binding assay, values are means \pm SEM for at least three independent experiments; for radioligand assay, values are means \pm range for two independent experiments. $*$ indicates values are significantly different compared with Rib500 BSA wk6 alone, $p<0.001$

Cellular responses to AGE-BSAs and inflammatory mediators. Two AGE-responsive cellular models were used to evaluate the biological activity of the AGE preparations with differing RAGE binding affinity. In the first model, VCAM-1 expression was studied using the HMEC-4 cell line, which does not constitutively express VCAM-1, but can be induced to by specific stimuli such as TNF- $\alpha$ and endotoxin treatment. In the second model, TNF- $\alpha$ secretion in response to AGE-BSA and LPS was studied in PBMCs.

According to published results, a 6-hour incubation period of endothelial cell monolayers with $100 \mu \mathrm{g} / \mathrm{ml}$ of AGE-albumin increased cell surface VCAM-1 expression by as much as seven-fold over control BSA treatment [21]. In the present study, the HMEC-4 cells were incubated with $100 \mu \mathrm{g} / \mathrm{ml}(1.5 \mu \mathrm{mol} / \mathrm{l})$ of the various AGE-BSAs (weeks 1-12) for $24 \mathrm{~h}$ (Fig. 4a). The two positive controls, TNF- $\alpha$ and LPS, strongly induced VCAM-1 expression (e.g. at 24-h time point: 24- and 18-fold increase over media control respec- 
a

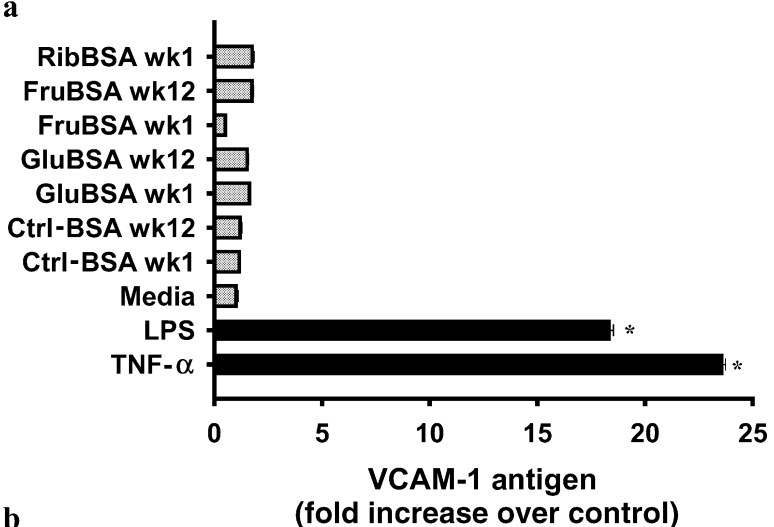

b

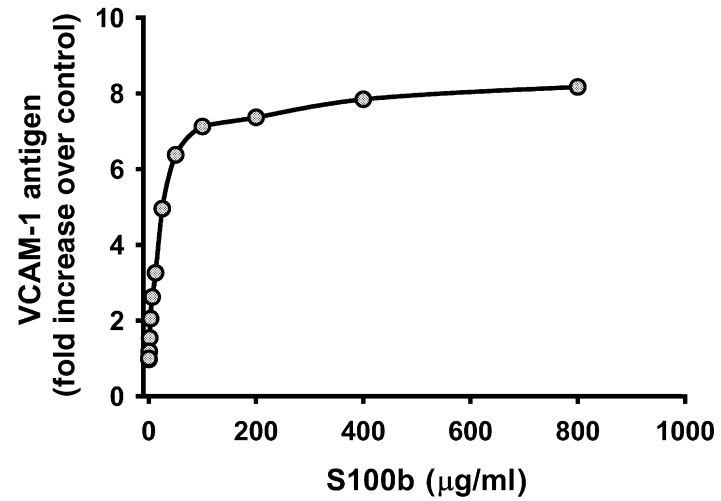

Fig. 4. Effects of AGE-BSAs, S100b, LPS and TNF- $\alpha$, on VCAM-1 expression on HMEC-4 cells. a. HMEC-4 cells were incubated for $24 \mathrm{~h}$ at $37{ }^{\circ} \mathrm{C}$ with $100 \mu \mathrm{g} / \mathrm{ml}(1.5 \mu \mathrm{mol} / \mathrm{l})$ of the indicated AGE-BSA. The same results were obtained after incubation for 48 and $72 \mathrm{~h}$ (data not shown). b. HMEC-4 cells were incubated with the indicated amounts of S100b for $24 \mathrm{~h}$ at $37{ }^{\circ} \mathrm{C}$. For positive controls, cells were also incubated with $20 \mathrm{ng} / \mathrm{ml} \mathrm{TNF}-\alpha$ or $200 \mathrm{ng} / \mathrm{ml}$ LPS. Cells were washed and the VCAM-1 ELISA was performed. Values are means \pm SEM of three independent experiments. * indicates values are significantly different compared with media control, $p<0.001$

tively). Unexpectedly, none of the AGE preparations was capable of inducing VCAM-1 expression above media control regardless of RAGE binding affinity. In addition, AGE-BSAs had no effect on VCAM-1 induction even after extending the incubation time to 48 and $72 \mathrm{~h}$ (data not shown). Similar results were obtained with primary human umbilical vein endothelial cells (data not shown). However, the known RAGE ligand, S100b, was titrated in this system and found to induce cell surface VCAM-1 expression on the HMEC-4 cells (Fig. 4b).

Stimulation of the NF- $\kappa B$ pathway by the AGEBSAs was assessed by monitoring degradation of I $\kappa \mathrm{B}-\alpha$, an inhibitor of NF- $\kappa \mathrm{B}$, using western blotting (Fig. 5). HMEC-4 cells showed the beginnings of I $\mathrm{B}-\alpha$ degradation after 8 min of exposure to TNF- $\alpha$, and then complete degradation after $20 \mathrm{~min}$. HMEC-4 cells treated with $\mathrm{S} 100 \mathrm{~b}$ showed I $\mathrm{KB}-\alpha$ degradation after $60 \mathrm{~min}$ of exposure. In contrast, HMEC-4 cells treated with Rib500 BSA wk6 at $300 \mu \mathrm{g} / \mathrm{ml}$ or

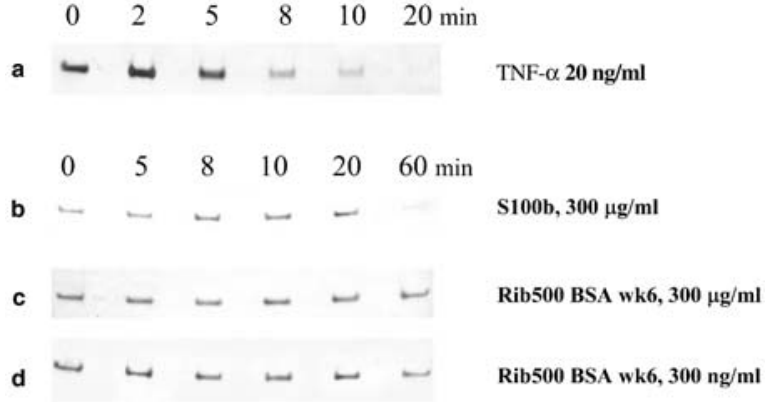

Fig. 5. Degradation of $\mathrm{I} \kappa \mathrm{B} \alpha$ in endothelial cells after various treatments. HMEC-4 cells were exposed to (a) $20 \mathrm{ng} / \mathrm{ml} \mathrm{TNF}-\alpha$, (b) $300 \mu \mathrm{g} / \mathrm{ml} \mathrm{S} 100 \mathrm{~b}$, (c) $300 \mu \mathrm{g} / \mathrm{ml}$ Rib500 BSA wk6 or (d) $300 \mathrm{ng} / \mathrm{ml}$ Rib500 BSA wk6 for the indicated time periods. Cell lysates were prepared and electrophoresis/immunoblotting performed employing rabbit anti-IאB $\alpha$ IgG

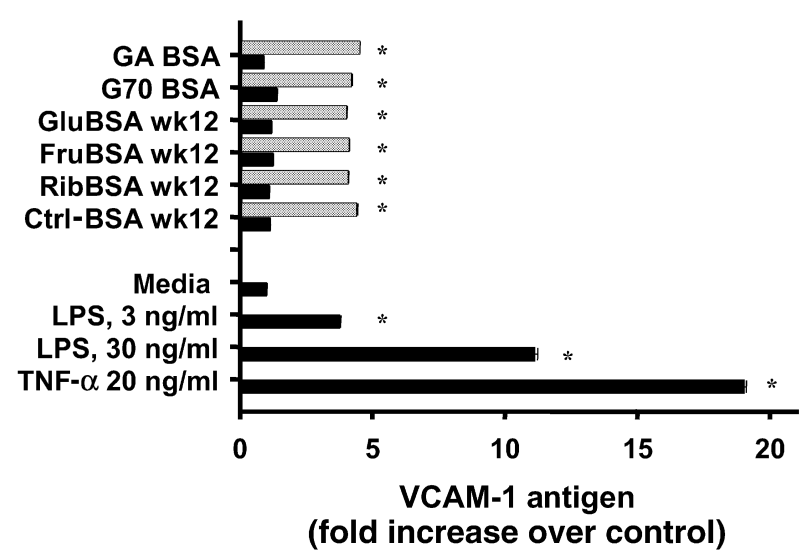

Fig. 6. Effect of AGE preincubation on VCAM-1 induction by LPS. HMEC-4 cells were preincubated with media alone or with one of the indicated AGE-BSA preparations $(3.6 \mu \mathrm{mol} / \mathrm{l})$ for $24 \mathrm{~h}$ at $37{ }^{\circ} \mathrm{C}$ (black bars). As indicated, some cells were then exposed to $3 \mathrm{ng} / \mathrm{ml}$ LPS for an additional $24 \mathrm{~h}$ at $37{ }^{\circ} \mathrm{C}$ (grey bars). The cells were washed and the VCAM-1 assay was performed. For positive controls, HMEC-4 cells were exposed to $20 \mathrm{ng} / \mathrm{ml} \mathrm{TNF-} \alpha$ or $30 \mathrm{ng} / \mathrm{ml}$ LPS. Values are means \pm SEM for three independent experiments. * indicates values are significantly different compared with media control, $p<0.001$

$300 \mathrm{ng} / \mathrm{ml}$ did not show I $\mathrm{KB}-\alpha$ degradation at any of the time points tested.

AGE-BSA induction of a primed cellular state was evaluated by preincubating HMEC-4 cells with the various AGE-BSAs at $240 \mu \mathrm{g} / \mathrm{ml}(3.6 \mu \mathrm{mol} / \mathrm{l})$ or with plain media for $24 \mathrm{~h}$ at $37^{\circ} \mathrm{C}$. Then, the cells were provided with a second stimulus by adding $3 \mathrm{ng} / \mathrm{ml}$ of LPS $\left(24 \mathrm{~h}\right.$ at $\left.37{ }^{\circ} \mathrm{C}\right)$ to mimic a bacterial infection. This level of LPS was sufficient to significantly increase VCAM-1 expression above baseline, but did not induce a maximal VCAM-1 response. When exposed to the low levels of LPS, the cells preincubated with the various AGEs did not show an increased VCAM-1 response compared with cells first exposed to media and then to the low level of LPS (Fig. 6). 

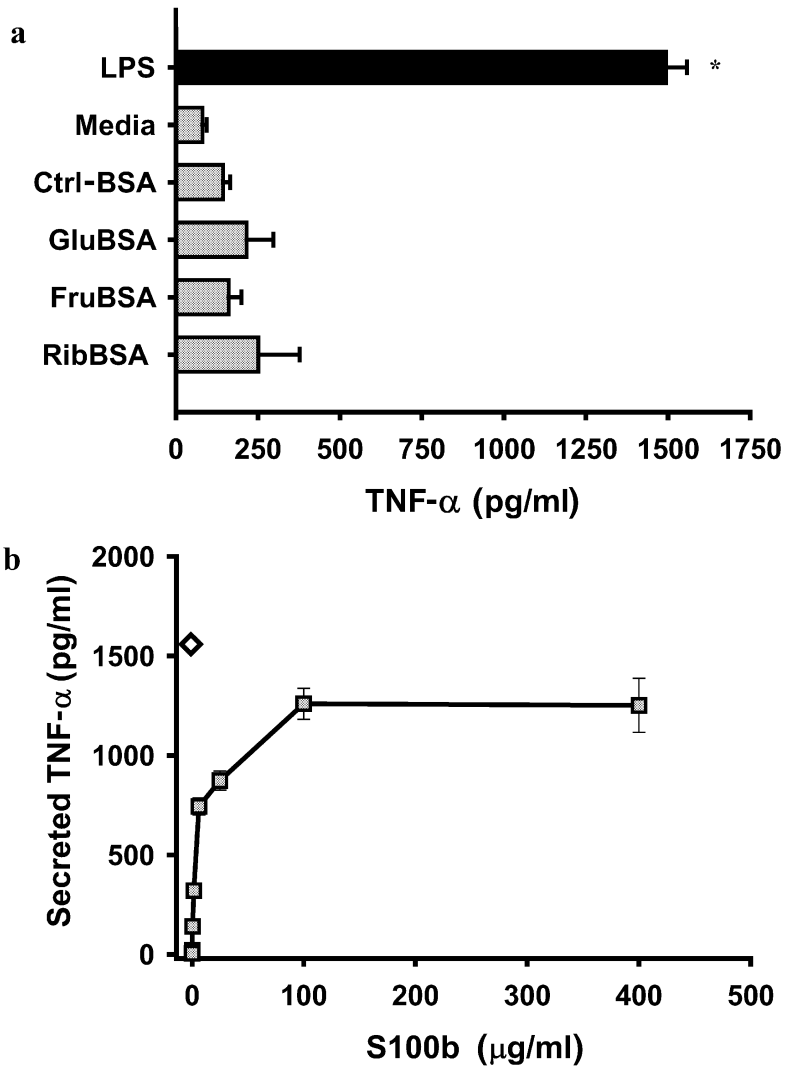

Fig. 7. TNF- $\alpha$ secretion by human PBMCs treated with AGEBSA, S100b or LPS. a. PBMCs were isolated from five different human donors. They were incubated for $18 \mathrm{~h}$ at $37{ }^{\circ} \mathrm{C}$ with the following treatments: $200 \mu \mathrm{g} / \mathrm{ml}$ of Rib500 BSA wk6, Fru500 BSA wk 6, Glu500 BSA wk6, Ctrl-BSA wk6, media alone and $100 \mathrm{ng} / \mathrm{ml}$ LPS. Values are means of TNF- $\alpha$ production \pm SEM for the five different donors under the six treatment conditions. b. TNF- $\alpha$ secretion by human PBMCs treated with S100b $(\square)$ or LPS $(\diamond)$ for $18 \mathrm{~h}$ at $37^{\circ} \mathrm{C}$. Experiment was repeated with three different donors. Graph is representative; values are means \pm SD. * indicates values are significantly different compared with media control, $p<0.001$

Because AGEs have been reported to robustly induce TNF- $\alpha$ secretion in phagocytic cells, AGE-BSAdependent cellular TNF- $\alpha$ secretion was assessed in primary human PBMCs. Expression of RAGE by the PBMCs was demonstrated by western blot (Fig. 1c). As indicated in Figure $7 \mathrm{a}$, an 18 -h incubation period with the AGE-BSAs did not induce significant TNF- $\alpha$ production by the PBMC cultures compared with CtrlBSA treatment or media control as measured by ELISA. For some individual experiments, there was up to a three-fold induction of TNF- $\alpha$ by AGE-BSA compared with control BSA cultures. Interestingly, the Ctrl-BSA exhibited modest TNF stimulatory activity. However, these results were variable between donors. In summary, there was not a significant difference between AGE-treated cultures and Ctrl-BSA groups. In contrast, treatment with $100 \mathrm{ng} / \mathrm{ml}$ of LPS reproducibly induced a significant TNF- $\alpha$ response in the PBMC cultures. Similar to the results found with the
HMEC-4 cells, the reported RAGE ligand S100b was also capable of inducing TNF- $\alpha$ production by the PBMCs in a dose-dependent manner (Fig. 7b).

\section{Discussion}

The objective of this study was to determine whether RAGE binding affinity correlated with cellular activation. To this end, we tested the ability of known RAGE ligands with varying RAGE binding affinity to bind to cells and induce VCAM-1 expression and TNF- $\alpha$ secretion. Because control BSA did not show cellular binding, AGE-BSA binding was dependent on AGE modifications rather than a determinant on BSA. In addition, RAGE binding affinity of our AGEs correlated with cellular association. Unexpectedly, we found that regardless of RAGE binding affinity and cellular association, all of the AGE preparations, which were free of significant levels of endotoxin contamination, failed to induce cell surface VCAM-1 on HMEC- 4 endothelial cells and TNF- $\alpha$ secretion by primary human PBMCs. Therefore, activation of cells expressing RAGE does not seem to correlate with RAGE binding. In our studies, we were not able to detect the AGE-specific increase in VCAM-1 and TNF- $\alpha$ secretion as previously reported $[21,22]$.

In contrast to the AGE-BSA treatments, we were able to confirm S100b induction of VCAM-1 and TNF- $\alpha$ secretion [18]. Interestingly, although both $\mathrm{S} 100 \mathrm{~b}$ and TNF- $\alpha$ induced I $\mathrm{B} \alpha \alpha$ degradation, cells treated with $\mathrm{S} 100 \mathrm{~b}$ required a significantly longer incubation time before I $\mathrm{I} \mathrm{B} \alpha$ degradation was visible (60 vs 8 min respectively; Fig. 5). Although our AGE preparations were generated using protocols similar to those previously reported, it is possible that our AGE preparations are more like RAGE antagonists: they are capable of binding to RAGE, but do not have yet to be discovered characteristic required for receptor activation. However, we have found that overnight preincubation of cells with various AGEs preparations cannot block the S100b-dependent induction of VCAM-1 on cultured endothelial cells (data not shown). Conversely, we have found pretreatment of cells with S100b reduced AGE cellular binding (Fig. 3). These results suggest that S100b may bind to multiple receptors, one of which is RAGE.

Our findings suggest that AGE proteins may not be general drivers of proinflammatory cellular responses mediated by NF-KB. Several possible factors could account for the inflammatory responses induced by AGE treatments previously reported, including endotoxin and metal ion contamination. Importantly for this study, the AGE preparations with no detectable levels of endotoxin were generated without the use of preservatives or endotoxin removal columns [24, 31, $32,33,34,35]$. The effects and possible interactions of preservatives or materials eluted from polymixin B 
columns with AGEs have not been evaluated, and it remains an open question as to whether these steps contribute to the biological activity of some AGE preparations. Finally, metal ions are another contaminant commonly found in AGE preparations. Various metal ions have been shown to drive inflammatory responses via generation of reactive oxygen species, leading to NF- $\kappa \mathrm{B}$ activation $[36,37]$. Hui et al. [38] reported that oxidant stress and endothelial permeability previously attributed to AGE proteins could be induced by redox-active metal ions found in the biological buffers commonly used to generate AGE preparations in vitro.

We also considered whether the absence of AGE biological activity was due to the activation state of the indicator cells. Since we used multiple cell types, including an immortalised cell line as well as primary cells from multiple donors, it is unlikely that the lack of biological activity of the AGE preparations used in this study was a function of cell type or culture conditions. In addition, the baseline levels and responses to positive control stimuli such as TNF- $\alpha$ and LPS by the cell types used in this study are similar to those in published findings $[18,21]$.

Our data indicate that binding to RAGE with high affinity is not sufficient to induce VCAM-1 and TNF$\alpha$ secretion in cells grown in vitro. In addition, it remains possible that only specific AGE modifications are capable of activating specific cell types. Overall, our findings do not confirm the role of AGE-RAGE interaction in driving inflammatory responses in vitro. Thus, how diverse AGE-modified proteins directly affect cell function remains to be resolved. The use of gene expression profiling of AGE-stimulated cells may help to clarify the role of AGEs in cell activation and these studies are currently underway.

Acknowledgements. Thanks to Dr Marla Weetall for helpful discussion of this work.

\section{References}

1. Hanssen KF (1997) Blood glucose control and microvascular and macrovascular complications in diabetes. Diabetes 46 [Suppl 2]:S101-S103

2. Nishikawa T, Edelstein D, Brownlee M (2000) The missing link: a single unifying mechanism for diabetic complications. Kidney International 58 [Suppl 77]:S26-S30

3. Ross R (1999) Atherosclerosis- an inflammatory disease. N Engl J Med 340:115-126

4. Krieglstein CF, Granger DN (2001) Adhesion molecules and their role in vascular disease. Am J Hypertens 14:44S-54S

5. Pradhan AD, Ridker PM (2002) Do atherosclerosis and type 2 diabetes share a common inflammatory basis? Eur Heart J 23:831-834

6. Schrör K (1997) Blood vessel wall interactions in diabetes. Diabetes 46 [Suppl 2]:S115-S118

7. Schiekofer S, Balletshofer B, Andrassay M, Bierhaus A, Nawroth PP (2000) Endothelial dysfunction in diabetes mellitus. Semin Thromb Hemost 26:503-511
8. Basta G, Lazzerini G, Massaro M et al. (2002) Advanced glycation end products activate endothelium through signal-transduction receptor RAGE: a mechanism for amplification of inflammatory responses. Circulation 105:816-822

9. Bierhaus A, Hofmann MA, Ziegler R, Nawroth PP (1998) AGEs and their interaction with AGE-receptors in vascular disease and diabetes mellitus I. The AGE concept. Cardiovasc Res 37:586-600

10. Dunn JA, McCance DR, Thorpe SR, Lyons TJ, Baynes JW (1991) Age-dependent accumulation of $\mathrm{N}$ epsilon-(carboxymethyl)lysine and $\mathrm{N}$ epsilon-(carboxymethyl)hydroxylysine in human skin collagen. Biochemistry 30:1205-1210

11. Reddy S, Bichler J, Wells-Knecht KJ, Thorpe SR, Baynes JW (1995) N-epsilon-(carboxymethyl)lysine is a dominant advanced glycation end product (AGE) antigen in tissue proteins. Biochemistry 34:10872-10878

12. Verzijl N, DeGroot J, Oldehinkel E et al. (2000) Agerelated accumulation of Maillard reaction products in human articular cartilage collagen. Biochem J 350:381387

13. Schleicher ED, Wagner E, Nerlich AG (1997) Increased accumulation of the glycoxidation product N(epsilon)(carboxymethyl)lysine in human tissues in diabetes and aging. J Clin Invest 99:457-468

14. Miyata T, Ishikawa S, Asahi K et al. (1999) 2-Isopropylidenehydrazono-4-oxo-thiazolidin-5-ylacetanilide (OPB-9195) treatment inhibits the development of intimal thickening after balloon injury of rat carotid artery: role of glycoxidation and lipoxidation reactions in vascular tissue damage. FEBS Lett 445:202-206

15. Vlassara H, Palace MR (2002) Diabetes and advanced glycation endproducts. J Intern Med 251:87-101

16. Neeper M, Schmidt AM, Brett J et al. (1992) Cloning and expression of a cell surface receptor for advanced glycosylation end products of proteins. J Biol Chem 267:1499815004

17. Brett J, Schmidt AM, Yan SD et al. (1993) Survey of the distribution of a newly characterized receptor for advanced glycation end products in tissues. Am J Pathol 143:1699-1712

18. Hofmann MA, Drury S, Fu C et al. (1999) RAGE mediates a novel proinflammatory axis: a central cell surface receptor for S100/calgranulin polypeptides. Cell 97:889901

19. Bucciarelli LG, Wendt T, Rong L et al. (2002) RAGE is a multiligand receptor of the immunoglobulin superfamily: implications for homeostasis and chronic disease. Cell Mol Life Sci 59:1117-1128

20. Yan SD, Schmidt AM, Anderson GM et al. (1994) Enhanced cellular oxidant stress by the interaction of advanced glycation end products with their receptors/binding proteins. J Biol Chem 269:9889-9897

21. Schmidt AM, Hori O, Chen JX et al. (1995) Advanced glycation endproducts interacting with their endothelial receptor induce expression of vascular cell adhesion molecule-1 (VCAM-1) in cultured human endothelial cells and in mice. A potential mechanism for the accelerated vasculopathy of diabetes. J Clin Invest 96:1395-1403

22. Miyata T, Hori O, Zhang J et al. (1996) The receptor for advanced glycation end products (RAGE) is a central mediator of the interaction of AGE-beta2microglobulin with human mononuclear phagocytes via an oxidant-sensitive pathway. Implications for the pathogenesis of dialysisrelated amyloidosis. J Clin Invest 98:1088-1094

23. Schmidt AM, Stern DM (2000) RAGE: a new target for the prevention and treatment of the vascular and inflammatory complications of diabetes. TEM 11:368-375 
24. Kislinger T, Fu C, Huber B et al. (1999) N(epsilon)-(carboxymethyl)lysine adducts of proteins are ligands for receptor for advanced glycation end products that activate cell signaling pathways and modulate gene expression. J Biol Chem 274:31740-31749

25. Valencia JV, Weldon SC, Quinn D et al. (2004) Advanced glycation endproduct ligands for the receptor for advanced glycation endproducts: biochemical characterization and formation kinetics. Anal Biochem 324:68-78

26. Ades EW, Candal FJ, Swerlick RA et al. (1992) HMEC-1: establishment of an immortalized human microvascular endothelial cell line. J Invest Dermatol 99:683-690

27. Skehan P, Storeng R, Scudiero D et al. (1990) New colorimetric cytotoxicity assay for anticancer-drug screening. J Natl Cancer Inst 82:1107-1112

28. Doi T, Vlassara H, Kirstein M, Yamada Y, Striker GE, Striker LJ (1992) Receptor-specific increase in extracellular matrix production in mouse mesangial cells by advanced glycosylation end products is mediated via plateletderived growth factor. Proc Natl Acad Sci USA 89:28732877

29. Radoff S, Makita Z, Vlassara H (1991) Radioreceptor assay for advanced glycosylation end products. Diabetes 40:1731-1738

30. Acton S, Resnick D, Freeman M, Ekkel Y, Ashkenas J, Kriegar M (1993) The collagenous domains of macrophage scavenger receptors and complement component $\mathrm{Clq}$ mediate their similar, but not identical, binding specificities for polyanionic ligands. J Biol Chem 268:3530 3537
31. Wautier MP, Chappey O, Corda S, Stern DM, Schmidt AM, Wautier JL (2001) Activation of NADPH oxidase by AGE links oxidant stress to altered gene expression via RAGE. Am J Physiol Endocrinol Metab 280:E685-E694

32. Boulanger E, Wautier MP, Wautier JL et al. (2002) AGEs bind to mesothelial cells via RAGE and stimulate VCAM-1 expression. Kidney Int 61:148-156

33. Still AW, He C, Vlassara H (1999) Characterization of the advanced glycation end-product receptor complex in human vascular endothelial cells. Biochem Biophys Res Commun 256:549-556

34. Bierhaus A, Chevion S, Chevion M et al. (1997) Advanced glycation end product-induced activation of NF-kappaB is suppressed by alpha-lipoic acid in cultured endothelial cells. Diabetes 46:1481-1490

35. Ivanov G, Kyurkchiev S (1998) Effect of advanced glycosylation end products on the activity of integrins expressed on U937 cells. Hum Immunol 59:325-330

36. Prasad AS, Bao B, Beck FW, Sarkar FH (2002) Zinc enhances the expression of interleukin-2 and interleukin-2 receptors in HUT-78 cells by way of NF-kappaB activation. J Lab Clin Med 140:272-289

37. She H, Xiong S, Lin M, Zandi E, Giulivi C, Tsukamoto H (2002) Iron activates NF-kappaB in Kupffer cells. Am J Physiol Gastrointest Liver Physiol 283:G719-G726

38. Hui YY, McAmis WC, Baynes JW, Schaeffer RC Jr, Wolf MB (2001) Effect of advanced glycation end products on oxidative stress in endothelial cells in culture: a warning on the use of cells studied in serum-free media. Diabetologia 44:1310-1317 